\title{
Аліна Гоцьв
}

Луганський національний університет імені Тараса Шевченка

\section{Бізнес у дзеркалі соціологічного теоретизування}

У статті підкреслюється важливість дослідження дефініції «бізнес» у соціологічному ракурсі, його теоретичне розкриття та аналіз. Бізнес є вагомим двигуном капіталістичної економіки будь-якої країни, від надання робочих місць до покриття попиту населення у певних товарах та послугах, що обумовлює актуальність наукового дослідження поняття. Завдяки теоретичному аналізу та аналізу статистичних даних, даних емпіричних досліджень розкрито бізнес в аспекті соціологічного теоретизування. У статті підкреслюється близькість понять «бізнес» та «підприємництво» в науковому дискурсі. Оцінено вплив науковців у становленні, впровадженні та поглибленні терміну. Виходячи з цього, приділено особливу увагу розмежуванню понять «підприємництво» та «бізнес», де розкрито три точки зору, що склалися в науковому дискурсі. Це повне ототожнення понять та їх розмежування (в одному випадку бізнес розглядається як ширше поняття ніж підприємництво, а в іншому навпаки). В соціології прийнято розмежовувати дані поняття та розглядати бізнес як більш змістовне поняття. Встановлено, що бізнес-це організована справа з більш прогнозованим прибутком, а підприємництво є діяльністю пов’язаною з ризиком. Виокремлено суб'єктів бізнесу, мету бізнесу, функції (латентні та явні), що говорить про певну структуру поняття. 3'ясовано, що на сьогодні існує широка класифікація бізнесу за різними критеріями, такими як розмір бізнесу, форма власності, вид економічної діяльності. Зосереджено увагу на критерії розміру перш за все. Виокремлено малий, середній та великий бізнес, наведені статистичні та соціологічні дані відносно цих типів, їх розповсюдженості в країні. Представлено ідею «капіталізму без капіталу». Встановлено, що бізнес розглядається як соціальний інститут в соціології, показано його інституціональний характер. 3’ясовано, що бізнес - це багатопрофільна економічна діяльність, соціальний інститут суспільства, що спрямований на отримання прогнозованого прибутку шляхом створення та реалізації певної продукції чи послуг.

Ключевые слова: бізнес, підприємництво, соціальний інститут, ринок, ринкова економіка, глобалізація, бізнесмен, підприємецьь

\section{Alina Hots \\ Luhansk Taras Shevchenko National University \\ Business in the mirror of sociological theorization}

The article emphasizes the importance of researching the definition of "business" in a sociological perspective, its theoretical disclosure and analysis. Business is a significant engine of the economy of any country, from the provision of jobs to the coverage of the demand of the population in certain goods and services, which causes the relevance of scientific research of the concept. Due to theoretical analysis and analysis of statistical data, empirical research data, business is revealed in the light of sociological theorization. The article emphasizes the proximity of the concepts of "business" and "entrepreneurship" in scientific discourse. The influence of scientists in the formation, implementation and deepening of the term was evaluated. Based on this, special attention is paid to the delimelation of the concepts of "entrepreneurship" and "business", where three points of view developed in scientific discourse are revealed. This is a complete definition of concepts and their distinction (in one case, business is considered as a broader concept than entrepreneurship, and in the other - vice versa). In sociology, it is customary to separate these concepts, and consider business as a more meaningful concept. It was established that business is an organized business with a more predictable profit, and entrepreneurship is an activity associated with risk. Business entities, business purpose, functions (latent and explicit) are distinguished, which indicates a certain structure of the concept. It has been found that today there is a wide classification of business according to various criteria, such as business size, ownership form, type of economic activity. Focus on size criteria above all. Small, medium and large businesses are distinguished, statistical and sociological data on these types and their distribution in the country are presented. It was established that business is considered as a social institution in sociology, its institutional character is shown. It was found out that business is a multidiscipnomal economic activity, a social institution of society aimed at obtaining projected profits through the creation and sale of certain products or services.

Keywords: business, entrepreneurship, social institution, market, market economy, globalization, businessman, entrepreneur 


\section{Постановка проблеми}

Плобалізаційні процеси в світі призвелидо впровадження ринкових механізмів регулювання економіки. Головними елементами ринкової економіки стали бізнес та підприємництво, без них не може розвиватися економічна система сучасного суспільства. 3 проголошенням незалежності в Україні набув активного розвитку бізнес, він почав розвиватися у різних галузях економіки.

На сьогодні бізнес має велике коло розповсюдженості, особливо 3 розвитком інтернету, тому розглядається як одне 3 основних завдань економіки країни, $\epsilon$ двигуном економіки світу. Малий та середній бізнес в сучасних умовах забезпечує країну робочими місцями, задовольняє потреби населення в товарах та послугах. Мале та середнє підприємництво $є$ провідним ринкоутворюючим сегментом економіки, основою ii конкурентного середовища, потужним рушієм соціального, економічного та науково-технічного розвитку суспільства, засобом реалізації підприємницького потенціалу населення. Воно відіграє важливу роль у створенні доданої вартості, забезпеченні зайнятості, розробці, впровадженні та комерціалізації інновацій (Небрат та ін., 2019). Однак, кризи, які виникають, впливають на функціонування підприємств із негативного боку. Для соціології як науки, що вивчає потреби та актуальні проблеми суспільства, тематика бізнесу, його теоретичний аналіз викликають інтерес в науковому дискурсі. Розгляд бізнесу як соціального інституту суспільства $€$ актуальним в умовах сьогодення.

\section{Аналіз публікацій}

Перші спроби наукового осмислення феномену підприємництва були зроблені в XVIII столітті P. Кантільйоном i Ж.-Б. Сеєм. Підприємців як власників капіталу в своїх працях аналізують класики політичної економії А. Сміт, Ф. Кене. Концепції капіталістичного підприємництва аналізують К. Маркс, М. Вебер, В. Зомбарт. Велику роль у подальшому науковому аналізі відігравало вчення Й. Шумпетера, а також П. Друкера, Г. Шмоллера та ін. Сучасний етап розвитку теорії підприємництва закріплений в працях межах економістів, таких як Д. Норт, О. Вільямсон та ін. Серед вітчизняних дослідників, які приділяли увагу феномену підприємництва у соціологічному розрізі, варто виділити О. Рахманова, С. Сірого, В. Пилипенка, О. Бондаренка та інших.

Мета даної статті полягає в розкритті бізнесу як соціального інституту сучасного суспільства, особливості його розвитку.

\section{Результати дослідження}

Бізнес (від давньоанглійського «bisid», що означає «активний», «діловий», «зайнятий роботою») - це багатопрофільна економічна діяльність, організована справа, яка спрямована на отримання прогнозованого прибутку шляхом створення та реалізації певної продукції чи послуг. Бізнес як соціальний інститут суспільства тісно пов'язаний 3 аналізом підприємництва як соціального феномену. Перші спроби наукового осмислення феномену підприємництва були зроблені в XVIII столітті Р. Кантільйоном і Ж.-Б. Сеєм. Р. Кантільйон (якому належить і сам термін «підприємництво») вже в XVIII в. побачив за ринковим господарством мережу взаємних обмінів, у яких підприємець виконував роль посередника, який несе тягар ризику i невизначеності. Діяльність підприємця як посередника припускала встановлення оптимальних зв'язків між виробниками i споживачами товарів, підприємницький прибуток розглядався в якості винагороди за ризики, викликані конкуренцією. Тобто, на думку автора, підприємець - це суб'єкт, діяльність якого тісно пов'язана з ризиком. Ж.-Б. Сей також бачив у підприємці не представника певного соціального класу, а будь-якого агента матеріального виробництва, що практично застосовує свої знання і навички з метою створення матеріальних цінностей, універсального посередника, який зв'язує між собою різних суб'єктів господарювання - виробників i споживачів, землевласників і фабрикантів тощо (Зарубіна, 2015).

АдамСмітперебувавпід значним впливом учення Р. Кантільйона і фізіократів. Він багато говорив про роботодавців, майстрів, купців і підприємців, акцентував увагу на економічній ролі підприємця, на джерелах доходу - прибутку на вкладений в справу капітал, на раціональності та утилітарності його діяльності в цілому (Болотов, 2011).

Інший напрямок вивчення 
підприємництва пов'язаний із соціальноісторичними і культурними дослідженнями. Макс Вебер (1905) в роботі «Протестантська етика i дух капіталізму» показує, як релігійні чинники стимулюють виникнення «підприємницького духу», який зіграв важливу роль у становленні промислового капіталізму. Підприємницька діяльність це втілення раціональності. Підприємцю притаманне ставлення до світу, яке Макс Вебер назвав «практичною раціональністю».

Ідеї Вебера розвивав у своїй роботі «Буржуа: етюди з історії розвитку сучасного економічного людини» (Зомбарт, 1913) німецький економіст і соціолог В. Зомбарт. Підприємницький дух - це синтез жадоби грошей, пристрасті до пригод і багато чого іншого. Якщо підприємець хоче мати успіх, він повинен бути одночасно завойовником організатором - торговцем.

Велике значення мало вчення Й. Шумпетера, який підприємництво розглядав як нерозривний зв'язок об'єктивної економічної функції і суб'єктивних якостей підприємця. У категорії «підприємництво» він вперше запропонував погляд на підприємця як новатора (Шумпетер, 1902). 3 його позиції підприємець - людинаініціатива, що впроваджує нові комбінації в виробництво. Тут наголошується, що потрібно «... робити не те, що інші і ... не так, як роблять інші». Підприємницький статус непостійний, так як суб'єкт ринкової економіки є підприємцем тільки тоді, коли здійснює функції новатора, і втрачає цей статус, як тільки переводить свій бізнес на рейки рутинного процесу.

П. Друкер, Г. Шмоллер, Ф. Тоссіг наголошують на активному, інноваційному характері соціальної та економічної дій підприємця і не лише у виборі 3 наявних альтернатив розподілу ресурсів, а й у створенні нових ринкових можливостей. П. Друкер (2007) погоджується з Шумпетером у поглядах та під нововведенням розуміє інструмент підприємців, засоби, за допомогою яких вони використовують зміни як сприятливу можливість для здійснення своїх задумів у сфері бізнесу та послуг. Цікавими є ідеї Друкера, що базою підприємництва є сучасні знання.

Сучасний етап розвитку теорії підприємництва характеризується зміщенням акценту 3 аналізу «суто економічних» дій підприємця більшою мірою на управлінські й соціокультурні аспекти. Зокрема, це окреслюється в межах інституційної економічної теорії (Коуз, Норт, Вільямсон та ін.).

Таким чином можна констатувати (розкривши основних дослідників), що довгий час не існувало терміну «бізнес» або його не відрізняли від поняття «підприємництво», саме це зумовлює аналіз походження терміну «бізнес» через поняття «підприємництво».

Сучасні підходи (Пилипенко В., Сірий Є., Рахманов О. тощо) аналізу підприємництва зосереджують увагу на таких ознаках, як статусні, функціональнорольові, особистісні (Рахманов, 2010). Є. Сірий (2008) зазначає, що «сьогодні змінюються суть бізнесу й уявлення про його цілі та основні функції. Зокрема в інформаційному, постіндустріальному суспільстві з більшою силою заяв ᄀляє про себе пошук і побудова цивілізованої моделі відносин між бізнесом і суспільством, що проглядається в соціально відповідальному підприємництві. Все більш розширюються і персоніфікуються цінності підприємницької етики...» Бізнес $є$ соціальним інститутом суспільства та має свої особливості у порівнянні $з$ підприємництвом, хоча вийшов із останнього.

Бізнес робиться заради одержання доходу (прибутку) від результатів діяльності у найрізноманітніших сферах - виробництві й торгівлі товарами та послугами, банківській та страховій справах, при проведенні транспортних, орендних i багато інших операцій як видів діяльності (Козловський, 2012).

Суб'єкт в бізнесі - це особи, які беруть активну участь у ділових відносинах. Це підприємці (бізнесмени), наймані працівники, споживачі, міжнародні організації, державні органи. 


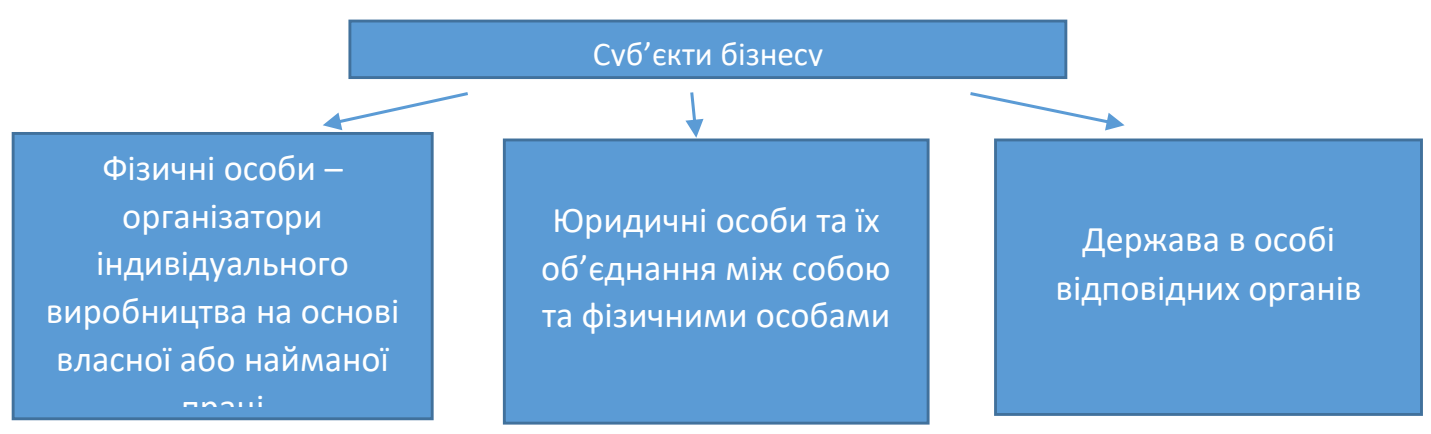

Рис. 1 Суб'єкти бізнесу

Мета бізнесу - це ті ключові результати, до яких прагне в своїй діяльності підприємство (фірма) протягом тривалого часу. Мета бізнесу з часом може змінюватися та залежить від характеру, ступеня розвитку та стану. Найголовніші $з$ цілей: отримання прибутку, накопичення необхідних засобів для розвитку бізнесу, надання суспільству товарів та послуг, досягнення передових позицій на ринку або в галузі. 3 позиції власників також цілі поділяються на: стратегічні цілі, цілі функціональних направленостей, цілі підрозділів та персональні цілі виконавців.

Бізнес виконує певні функції в суспільстві, так виокремимо явні та латентні функції бізнесу. Явні функції бізнесу - ті, що збігаються з відкритими цілями та задачами організації, системи, інституту (наприклад, освоєння нових джерел і видів сировини або ведення нових методів виробництва тощо). Латентні функції - виявляють себе лише 3 плином часу і відрізняються від проголошуваних намірів учасників діяльності (наприклад, функція ефективного задоволення попиту населення на товари чи послуги). Тобто явні функції бізнесу спрямовані на досягнення індивідуальних за своїм характером цілей бізнес-діяльності i перш за все максимально високого прибутку як міри підприємницького успіху, тобто це економічні функції. Латентні функції бізнесу є громадськими за своїм характером, тобто соціальними (Іванов, 2014). Головною $\epsilon$ функцією бізнесу в державі є загальноекономічна функція, тобто підвищення економіки та працевлаштування населення.

Як вже зазначали вище, в науковому дискурсі склалися різні підходи до визначення поняття «бізнес» та його співвіднесення 3 близьким (родовим) поняттям «підприємництво».

Бізнес та підприємництво - це синоніми. Поняття «бізнесмен» розглядається як англомовний аналог, переклад терміну «підприємець». Такий підхід закріплений в українському законодавстві, проте $є$ дуже дискурсивним.

Бізнес та підприємництво - різні поняття. Бізнес є ширшим ніж підприємництво. Як зазначає Рахманов О. (2017), підприємництво розглядається як динамічний, активний елемент бізнесу. Він включає в себе не тільки підприємців, а й найманих працівників, споживачів, державні структури. Підприємець завжди $є$ бізнесменом, але бізнесмен далеко не завжди є підприємцем. Починаючи свою справу, підприємець виступає як підприємець, але найчастіше (особливо в малому підприємстві), вивівши його на стаціонарний режим, займається рутинною управлінською діяльністю 3 утримання свого бізнесу в цьому режимі.

Підприємництво розглядається також так, що підсумком підприємницької діяльності є створення бізнесу, а мета бізнесу - отримання прибутку.

Підприємництво ширше за бізнес. Бізнес - це діяльність, що спрямована на отримання прибутку шляхом реалізації та створення певної продукції, має більш прогнозований характер. Підприємництво ж $є$ ризиковою діяльністю, що пов'язана 3 новаторством. Бізнес розуміється як діяльність, спрямована на отримання прибутку, підприємництво - як творчість, новаторство (господарське, ділове і т. д.). П. Друкер (2007) відрізняє підприємництво від бізнесу, акцентуючи увагу на тому, що «не кожен новий 
малий бізнес є підприємницьким і являє підприємництво». Бізнес більш загальне поняття процесу створення нової вартості, прибутку підприємця. В процесі бізнесу використовується вже наявна на той час ідея, патент, власний винахід підприємця.

3 іншого боку, в уже готовому, що функціонує, бізнесі постійно повинні застосовуватисяновітехнології, застосуються нові, більш ефективні способи організації бізнесу. Все це можливо при наявності підприємництва або, можна сказати, духу підприємництва. У вже працюючому бізнесі основні його власники повинні створювати умови, щоб кожен співробітник організації відчував себе підприємцем.

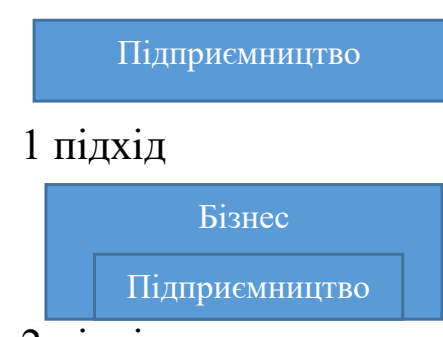

2 підхід
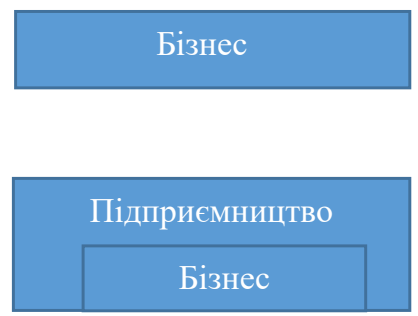

3 підхід

\section{Рис. 2. Підходи до співвідночення понять «підприємництво» та «бізнес»}

Ми вважаємо, що, 3 точки зору соціології, бізнес та підприємництво $€$ різними поняттями, бізнес - це організована справа з більш прогнозованим прибутком. Підприємництво - діяльність, пов'язана 3 ризиком. Прикладом бізнесу $є$ фабрика, а підприємництва - торгова точка на базарі.

В чому ж різниця між бізнесменом та підприємцем виходячи з цього. Підприємець - це людина, яка ризикує та створює або модернізує нові ідеї для бізнесу, для більшого заробітку. Класичним прикладом підприємця, що наводиться в літературі, $\epsilon$ Марк Цукерберг. Бізнесмен же працює зі вже готовою моделлю, у вже перевірених сферах; приклад - Павло Дуров.

Це як приклад, а так на сьогодні можна говорити про різні типи бізнесу за різноманітними критеріями. Так, за розміром виокремлюють: малий, середній та великий бізнес.

За даними Державної служби статистики станом на 2019 рік в Україні зареєстровано 380597 підприємств, 3 них 518 великих підприємств (0.1\% до загальної кількості), середніх - 17751 або 4,7 \% та малих - 362628 (95,2\%) (Укрстат, 2020).

Існують різні підходи до визначення малого або середнього та великого бізнесу, проте, згідно Господарського кодексу України (2020), маємо визначення згідно кількісного підходу. Так, малий бізнес - фірми з числом зайнятих до 50 осіб та обсягом чистого доходу до 10 млн. евро на рік (Господарський кодекс, 2020).

Прикладом можуть бути франчайзинг. Франчайзинг - це підприємницька діяльність, згідно 3 якою на договірній основі одна сторона (франчайзер) передає другій за винагороду на певний строк або без зазначення такого право використання торгової марки; знаку для послуги; фірмового найменування; послуг; технологічного процесу; спеціалізованого обладнання; ноу-хау; комерційної інформації, що охороняється законом; інших, передбачених договором об'єктів права інтелектуальної власності (Термінологічний словник, 2020). Франчайзинг - це один із інструментів розвитку бізнесу, який довго й ефективно «працює» в розвинених економіках. В Україні франчайзинг з'явився понад 20 років тому. Одними з перших закладів, що працювали за франшизою, стали McDonald's та Pizza Celentano. Так, за даними Franchise Group (консалтингової компаніï), на першу половину 2019 року в країні нараховувалось 504 франчайзера, що на $18 \%$ більше в порівнянні з цим же періодом попереднього року (Зайцев та Кордас, 2020). В світі лідером серед країн вважаються США, а серед компаній - McDonald's продовжує зберігати лідерство серед франчайзерів, маючи понад 38000 точок по всьому світу. Діяльність компанія розпочала у 1940 р., а у 1955 р. створила першу свою франшизу. 
Нині компанія вимагає від нових франчайзерів мінімум 500000 \$ власних коштів (Серова, 2019).

Малий бізнес найсуттєвіший до змін або криз в суспільстві. Наприклад, через спричинену коронавірусом кризу за даними Європейської Бізнес Асоціації (СБА) 33 \% малих підприємств в Україні втратили від 50 до 75 \% доходів. Сім відсотків підприємств розглядають варіант закриття (Криза в Україні: малий бізнес стрімко втрачає доходи - опитування, 2020). Згідно останніх даних, що проводить Свропейська Бізнес Асоціація, зменшилась кількість тих, кого не влаштовує поточна економічна ситуація - 29,2\% проти $38,4 \%$ у минулому році (Дослідження European Business Association).

Найбільше, за даними статистики підприємств малого бізнесу, зосереджено у таких сферах, як оптова та роздрібна торгівля; ремонт автотранспортних засобів і мотоциклів - 98087 станом на 2019 рік. А найменше у сферах: мистецтво, спорт, розваги і відпочинок та освіта (Укрстат, 2020). Малі та середні підприємства займають велику частку в таких галузях, як будівництво, адміністративне та допоміжне обслуговування, професійна, наукова та технічна діяльність, в кожній 3 яких на них припадає понад 90\% зайнятості. Крім того, на МСП припадає більш як 70\% зайнятості в секторах торгівля, сільське, лісове та рибне господарство, інформаційні послуги (Аналітичні матеріали, 2020). Всі ці сфери (особливо готельно-ресторанний бізнес, роздрібна торгівля, а також фінансовий та банківський сектор) на українському ринку праці зазнали найбільших збитків від пандемії (Гоць, 2020). Якщо ми говоримо про франчайзинг як приклад малого бізнесу, то він не так сильно піддається негативному впливу зовні та більш стійкий до економічних криз у суспільстві порівняно, наприклад, з маленьким магазином одягу невідомого бренду.

Середній бізнес - організації з середньою кількістю співробітників від 51 до 250 осіб та обсягом чистого доходу до 50 млн євро (Господарський кодекс, 2020). Середній бізнес найбільше зосереджений в таких сферах, якпромисловість, оптоватароздрібна торгівля, ремонт автотранспортних засобів i мотоциклів, сільське, лісове та рибне господарство $(5025,3185$ та 2281 одиниць відповідно). Найменше одиниць зафіксовано у сфері освіти - 55 одиниць (Укрстат, 2020).

Суб'єктами великого підприємництва є юридичні особи - суб'єкти господарювання будь-якої організаційно-правової форми та форми власності, у яких середня кількість працівників за звітний період (календарний рік) перевищує 250 осіб, та річний дохід від будь-якої діяльності перевищує суму, еквівалентну 50 мільйонам євро, визначену за середньорічним курсом Національного банку України (Господарський кодекс, 2020).

Великий бізнес $\epsilon$ основою сучасної економіки. Це корпорації, об’єднання, товариства. Найбільший вплив на розвиток бізнесу мають транснаціональні корпорації. Найзагальніше визначення ТНК - це міжнародні за складом і характером діяльності суб'єкти господарського життя, які функціонують на принципах корпоративної власності 3 акціонерною формою управління та розподілу прибутків у міжнародному масштабі (Алішов Гамід Надір-огли, 2016). Глобалізація позбавила українських виробників захисту від світової конкуренції національними кордонами, вони були змушені або трансформуватися в компанії міжнародного класу, або згортати виробничі потужності та виводити фінансові активи за кордон (Курінько, 2020).

До рейтингу найвпливовіших корпорацій світу увійшли Apple, Amazon i Microsoft. Також до першої десятки потрапили Walt Disney, Starbucks, Berkshire Hathaway, Alphabet (материнська компанія Google), JPMorgan Chase, Netflix i Costco Wholesale. Перше місце списку 2021 року посіла корпорація Apple, яка утримує лідерство вже 14 років поспіль (Global 500 FORTUNE, 2020). Сьогодні з' явилось поняття «капіталізм без капіталу», по всьому світу компанії вкладають кошти в нематеріальні продукти виробництва, відбувається підйом неречових активів. Наприклад, у 2006 р. ринкова вартість Microsoft досягла 250 млрд дол. США. Згідно бухгалтерського балансу компанії, активи оцінюються приблизно у 70 млрд дол., 3 яких 60 млрд дол. склали грошові засоби, різні фінансові інструменти, а на традиційні активи (техніка, обладнання) припало лише 3 млрд дол. або 4 \% загальної вартості активів Microsoft (Хаскел та Вестлейк).

Залежно від видів економічної діяльності, виділяють бізнес виробничий, 
консультативний, комерційний, фінансовий. За даними Держстату оптова та роздрібна торгівля перебуває на першому місці за часткою ВВП (14\%). Серед лідерів також переробна промисловість (12\%) та сільське господарство (11\%). Ці три сфери разом дають близько 40\% ВВП (Країна торговців, програмістів та перукарів..., 2019).

Окрім наведеної класифікації також можна виокремити в залежності від форми організації бізнесу: індивідуальне підприємство, партнерство, корпорація, кооператив, акціонерне співтовариство, товариство з обмеженою відповідальністю, корпорація.

За походженням капіталу бізнес може бути іноземний, національний та змішаний. Експансія іноземних ТНК на український ринок розпочалася одразу ж після проголошення незалежності України у 1991 р. Це мова йде про ТНК, які з'являлися в різний час та $з$ розвитком глобалізації їх чисельність збільшується.

А за формою власності: державні, приватні та колективні (акціонерні співтовариства, кооперативи тощо) підприємства. Це не повна типологія дефініції «бізнес», але найсуттєвіша.

Бізнес як соціальний інститут проаналізуємо через визначення соціального інститут, його ознак та структури за I. Рущенко (Рущенко, 1996, с. 279-280). Так, до структури соціального інституту зараховують: маси людей або спеціалізовані групи, зайняті стереотипною діяльністю певного напрямку або змісту. Мова йде про суб'єктів бізнесу, технології, знаряддя праці та матеріальні ресурси, необхідні для реалізації певного виду діяльності. Залежно від сфери та статусу бізнесу дані ресурси мають місце бути, вони доволі різнобічні. Це може бути безпосередньо знаряддя для виконання певного виду діяльності та, наприклад, інвестиції для розвитку бізнесу; регулятори діяльності у вигляді наборів цінностей, символів, норм, правил, кодексів, традицій, санкцій. Підприємницька діяльність в Україні регулюється низкою нормативно-правових актів, таких як Конституція України, Закон України «Про підприємство», Закон України «Про господарські товариства», «Про власність», «Про розвиток та державну підтримку малого i середнього підприємництва в
Україні» та ін.; соціальні ролі відповідно до розподілу праці та характеру діяльності вкупі 3 організаційними схемами та прийомами, що реалізуються у межах спеціалізованих закладів, установ, підприємств тощо. Роль керуючого, власника або працівника безпосереднього виробництва наприклад.

Висновки. Бізнес - це соціальний інститут суспільства, який функціонує у всіх сферах людської діяльності, є структурним елементом сучасної суспільної системи, відповідає всім ознакам та критеріям соціальних інститутів. Модернізаційні процеси в світі впливають на бізнес та роблять його більш могутнім механізмом ринкової економіки. Встановлено, що сьогодні бізнес в Україні $\epsilon$ інституціолізованим, визначені соціальні ролі та соціальні норми учасників підприємницької діяльності на законодавчому рівні. З'ясовано, що в науковому дискурсі розділяються поняття бізнес та підприємництво, хоча витоки дефініції «бізнес» походять від поняття «підприємництво». Виходячи 3 головної мети, маємо спільний аспект - це отримання прибутку. Незважаючи на те, що бізнес як складне соціально-економічне явище пройшов довгий шлях свого становлення, в українському дискурсі досі немає єдиного розуміння та визначення терміну, особливо у розмежуванні з поняттям «підприємництво». Встановлено, що бізнес $є$ справою, діловою активністю, направленою на вирішення завдань, пов'язаних у кінцевому рахунку зі здійсненням на ринку операцій обміну товарів i послуг між економічними суб'єктами ринку, з використанням форм та методів конкретної діяльності, які склалися в ринковій практиці. Виявлено, що малий, середній та великий бізнес мають свої особливості функціонування в країні. В економіці важливого значення набуває малий та середній бізнес, який $\epsilon$ важливим регулятором на ринку праці, водночас саме ці типи бізнесу найбільш різко реагують на кризи в суспільстві. Сьогодні ми маємо наймогутніші бізнес системи, що пов'язані насамперед з інформаційними технологіями, «капіталізм без капіталу». Треба зазначити, що дефініція «бізнес» $\epsilon$ вкрай актуальною в умовах капіталістичних відносин та потребує вивчення 3 боку як теоретичної, так і емпіричної соціології. 


\section{БІБЛІОГРАФІЧНІ ПОСИЛАННЯ}

Global 500 FORTUNE. Retrieved from https://fortune.com/global500

Алішов Гамід Надір-огли. Роль транснаціональних компаній у розвитку національної економіки України. Ефективна економіка. 2016. № 4.

Аналітичні матеріали. Портал для підприємців. Огляд малого та середнього підприємництва в Україні. 2018/2019. Квітень, 2020. URL: https://sme.gov.ua/analytics/

Болотов Г. П., Дерій Ж. В., \& Семченко О. Б. Генеза та розвиток теорій підприємництва. Вісник Чернігівського державного технологічного університету. Серія «Економічні науки». 2011. № 4 (54).

Вебер М. Протестантская этика и дух капитализма. 1905. URL: http://filosof.historic.ru/books/item/f00/s00/ z0000297/index.shtml

Господарський кодекс України від 21.07.2020 № 819-IX. URL: https://zakon.rada.gov.ua/laws/show/436$15 \#$ Text

Гоць А. Зайнятість і безробіття на українському ринку праці: вплив пандемії COVID-19. Соччіальні технологї: актуальні проблеми теорії та практики. 2020. Вип. 88.

Дослідження European Business Association. URL: https://eba.com.ua/research/doslidzhennya-ta-analityka/

Друкер П. Бизнес и инновации. Москва : Вильямс, 2007. 432 с.

Зайцев O., \& Кордас А. Поточний стан франчизінгу в Україні та у світі. Проблеми та перспективи економіки та управління. 2020. №1 (21). С. 53-62.

Зарубіна Н. Н. Економічна соціологія. 2015. URL: https://stud.com.ua/24800/sotsiologiya/ekonomichna sotsiologiya

Зомбарт В. Буржуа: Этюды по истории духовного развития современного экономического человека. Москва : Наука, 1994. 443 с.

Іванов Л. Н. Психологія бізнесу. 2014. URL: https://stud.com.ua/52787/psihologiya/funktsiyi_biznesu_ sotsialnogo institutu

Козловсьький В. О. Підприємництво. Навчальний посібник. Вінниця, 2012. 221 с.

Країна торговців, програмістів та перукарів: які бізнеси найбільш популярні в Україні. 2019. URL: https:// www.epravda.com.ua/publications/2019/10/9/652388/

Криза в Україні: малий бізнес стрімко втрачає доходи - опитування. 2020. URL: https://www.dw.com/uk/ криза-в-україні-малий-бізнес-стрімко-втрачає-доходи-опитування/а-53589942

Курінько Р. (2020). Соціальна відповідальність бізнесу в Україні: проблеми прийняття та становлення. Науково-теоретичний альманах «Грані», 23 (12), 38-46. doi: 10.15421/1720110.

Небрат В. В., Супрун Н. А. та ін. Підприємництво в Україні: історико-інституційний аналіз : монографія.

В. В. Небрат (ред.); НАН України, ДУ «Ін-т екон. та прогнозув. НАН України». Київ, 2019. 532 с.

Показники діяльності суб'єктів великого, середнього, малого та мікропідприємництва. URL: http://www. ukrstat.gov.ua (дата звернення - 14.03.2020)

Рахманов О. Соціокультурні чинники інституціоналізації підприємництва в Україні: монографія. Київ : КНЕУ. 2010. 179 c.

Рахманов О. С. Соціалізація та ідентифікація особистості в суспільстві: навч.-метод.комплекс. Київ :

КНЕУ. 2017. 17 c.

Рущенко І. П. Соціологія: курс лекцій. Харків, 1996.

Серова I. А., \& Шаповалова В. О. Бізнес-статистика. Конспект лекцій. Харків. ХНЕУ, 2009. 88 с.

Сірий $Є$. Підприємництво як предмет теоретико-соціологічного осмислення: розгорнення проблеми. Украӥнський сочіум. 2008. № 4 (27). С. 33-43.

Термінологічний словник. Асоціація франчайзингу України. URL: http://abc.franchising.org.ua/ (дата звернення: 23.11.2020).

Хаскел Дж, \& Вестлейк С. Капитализм без капитала: подъём нематериальной экономики. Экономическая социология. 2021. Т. 22. № 1.

Шумпетер Й. А. Теория экономического развития. Москва: Прогресс, 1982.

\section{REFERENCES}

Global 500 FORTUNE (2020). Retrieved from: https://fortune.com/global500 [in Ukrainian].

Alishov Ghamid Nadir-oghly (2016). Rolj transnacionaljnykh kompanij u rozvytku nacionaljnoji ekonomiky Ukrajiny [The role of multinational companies in the development of the national economy of Ukraine.] Efektyvna ekonomika, 4 [in Ukrainian].

Analitychni materialy. Portal dlja pidpryjemciv (2020). Oghljad malogho ta serednjogho pidpryjemnyctva v Ukrajini. 2018/2019 [Analytical materials. Portal for entrepreneurs / Overview of small and medium-sized enterprises in Ukraine. 2018/2019]. URL: https://sme.gov.ua/analytics/ [in Ukrainian].

Bolotov, Gh. P., Derij, Zh. V., \& Semchenko, O. B. (2011). Gheneza ta rozvytok teorij pidpryjemnyctva [Genesis and development of entrepreneurship theories]. Visnyk Chernighivsjkogho derzhavnogho tekhnologhichnogho universytetu. Serija "Ekonomichni nauky", 4 (54) [in Ukrainian].

Veber, M. (1905). Protestantskaja jetika i duh kapitalizma [Protestant ethics and the spirit of capitalism]. URL: http:// filosof.historic.ru/books/item/f00/s00/z0000297/index.shtml [in Russian]. 
Ghospodarsjkyj kodeks Ukrajiny vid 21.07.2020 № 819-IKh [Commercial Code of Ukraine]. URL: https://zakon.rada. gov.ua/laws/show/436-15\#Text [in Ukrainian].

Ghocj, A. (2020). Zajnjatistj i bezrobittja na ukrajinsjkomu rynku praci: vplyv pandemiji COVID-19 [Employment and unemployment in the Ukrainian labor market: the impact of the COVID-19 pandemic]. Socialjni tekhnologhiji: aktualjni problemy teoriji ta praktyky, Vyp. 88 [in Ukrainian].

Doslidzhennja European Business Association. URL: https://eba.com.ua/research/doslidzhennya-ta-analityka/ [in Ukrainian].

Druker, P. (2007). Biznes i innovacii [Business and innovation]. Moskva : Vil'jams [in Russian].

Zajcev, O., \& Kordas, A. (2020). Potochnyj stan franchyzinghu v Ukrajini ta u sviti [The current state of franchization in Ukraine and in the world]. Problemy ta perspektyvy ekonomiky ta upravlinnja, 1 (21), 53-62 [in Ukrainian].

Zarubina, N. N. (2015). Ekonomichna sociologhija [Economic sociology]. URL: https://stud.com.ua/24800/ sotsiologiya/ekonomichna_sotsiologiya [in Ukrainian].

Zombart, V. (1994). Burzhua: Jetjudy po istorii duhovnogo razvitija sovremennogo jekonomicheskogo cheloveka [Bourgeois: A study on the history of the spiritual development of modern economic man]. Moskva : Nauka [in Russian].

Ivanov, L. N. (2014). Psykhologhija biznesu [Psychology of business]. URL: https://stud.com.ua/52787/psihologiya/ funktsiyi biznesu sotsialnogo institutu [in Ukrainian].

Kozlovsjkyj, V. O. (2012). Pidpryjemnyctvo [Entrepreneurship]. Vinnycja. URL: http://kozlovskiy.vk.vntu.edu.ua/ file/1/a5e342f38b2bbef4c60f404f570be00d.pdf [in Ukrainian].

Krajina torghovciv, proghramistiv ta perukariv: jaki biznesy najbiljsh populjarni v Ukrajini (2020). [Country of traders, programmers and hairdressers: which businesses are the most popular in Ukraine]. URL: https://www.epravda.com.ua/ publications/2019/10/9/652388/ [in Ukrainian].

Kryza v Ukrajini: malyj biznes strimko vtrachaje dokhody - opytuvannja (2020). [Crisis in Ukraine: small business is rapidly losing revenues - poll]. URL: https://www.dw.com/uk/kryza-v-ukrajini-malyj-biznes-strimko-vtrachaje-dokhodyopytuvannja/a-53589942 [in Ukrainian].

Kurinko, R. (2020). Sotsialna vidpovidalnist biznesu v Ukraini: problemy pryiniattia ta stanovlennia [Social business responsibility in Ukraine: problems of acceptance and formation]. Scientific and theoretical almanac "Grani», 23 (12), 38-46. doi: 10.15421/1720110 [in Ukrainian].

Pokaznyky dijaljnosti sub'jektiv velykogho, serednjogho, malogho ta mikropidpryjemnyctva [Entrepreneurship in Ukraine: Historical and Institutional Analysis]. URL: http://www.ukrstat.gov.ua (data zvernennja - 14.03.2020) [in Ukrainian].

Rakhmanov, O. (2010). Sociokuljturni chynnyky instytucionalizaciji pidpryjemnyctva v Ukrajini [Socio-cultural factors of institutionalization of entrepreneurship in Ukraine]. Kyiv : KNEU [in Ukrainian].

Rakhmanov, O. S. (2017). Socializacija ta identyfikacija osobystosti v suspiljstvi [Socialization and identification of personality in society]. Kyiv : KNEU [in Ukrainian].

Rushhenko, I. P. (1996). Sociologhija: kurs lekcij [Sociology: course of lectures]. Kharkiv [in Ukrainian].

Sjerova, I. A., \& Shapovalova, V. O. (2009). Biznes-statystyka [Business Statistics]. Kharkiv : KhNEU [in Ukrainian].

Siryj, Je. (2008). Pidpryjemnyctvo jak predmet teoretyko-sociologhichnogho osmyslennja: rozghornennja problem [Entrepreneurship as a subject of theoristic and sociological comprehension: the unfolding of the problem]. Ukrajinsjkyj socium, 4 (27), 33-43 [in Ukrainian].

Terminologhichnyj slovnyk [Terminology dictionary]. Asociacija franchajzynghu Ukrajiny. URL: http://abc. franchising.org.ua/ (data zvernennja: 23.11.2020) [in Ukrainian].

Khaskel, Dzh., \& Vestlejk, S. (2021). Kapytalyzm bez kapytala: podjom nemateryaljnoj ekonomyky [Capitalism without Capital: The Rise of the Intangible Economy]. Ekonomycheskaja socyologhyja, 22 (1) [in Russian].

Shumpeter, J. A. (1982). Teorija jekonomicheskogo razvitija [Theory of economic development.]. Moskva : Progress [in Russian].

Gots Alina

Ph.D., Assoc. Prof, https://orcid.org/0000-0001-9675-8032,ukolova_alina@ukr.net

Стаття надійшла / Article arrived: 08.02.2021

Схвалено до друку / Accepted: 15.03.2021 